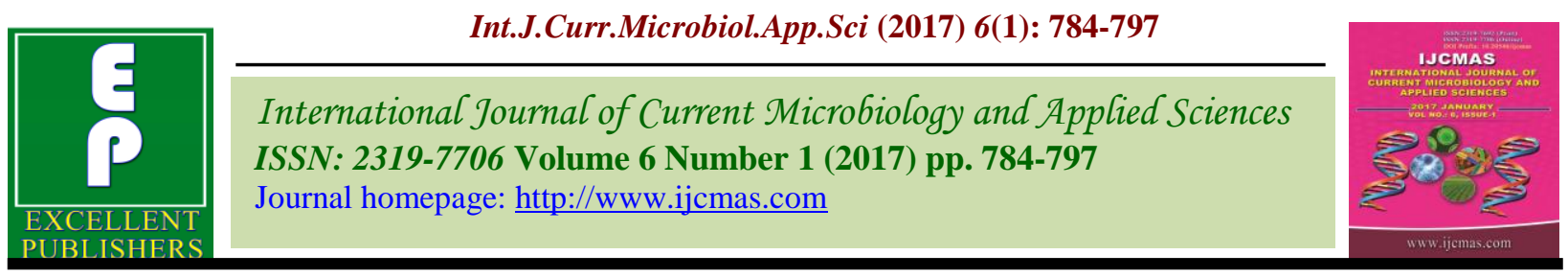

Original Research Article

http://dx.doi.org/10.20546/ijcmas.2017.601.093

\title{
Quality Characterization of Giblets of Indigenous Indian Chicken Breeds
}

\author{
Veer Pal Singh* and Vikas Pathak \\ Department of Livestock Products Technology, College of Veterinary Science and Animal \\ Husbandry, U.P. Pt. D.D.U. Veterinary University \& Go Anusandhan Sansthan, \\ Mathura, U.P. India 281001 \\ *Corresponding author
}

A B S T R A C T

\section{Keywords}

Chicken,

Giblets,

live weight,

carcass weight, quality.

Article Info

Accepted:

29 December 2016

Available Online:

10 January 2017
A study was conducted to know the ratio of giblets on live weight and carcass weight basis of various indigenous chicken breeds. The nutritional value of giblets was also assessed to use a source of nutrition in value added products. Birds of six weeks each of Cobb-400, Vanraja, Aseel, Kadaknath breed reared under deep litter system were sacrificed using halal slaughter procedure. Giblets were collected and processed as per standard procedure. Each and every measurement was taken using digital measurement twice for every reading. Proximate analysis was performed using ISO procedures. Significant $(\mathrm{P}<0.05)$ differences were observed in giblets yield both on hot and cold weight basis in respect to live weight. Organs of giblets individually showed significant $(\mathrm{P}<0.5)$ differences among various breeds/strain. The nutritional parameters like moisture, fat, protein and ash in general showed significant $(\mathrm{P}<0.05)$ differences among the breeds with few exceptions. Heart was highest in total fat, and lowest in protein content. Liver was highest in protein and total ash content while gizzard was highest in moisture and lowest in total fat. Some experiments on amino acid profile and fatty acid profile is also required for further know how about the actual nutritional status of chicken giblets. Giblets are the integral parts of chicken carcass but its nutritional value and proportion in different chicken breeds is still not fully understood. So the present study may open the avenue of its uses in value addition and other variety products.

\section{Introduction}

White meat is considered superior for health over red meat due to low fat and cholesterol content and as an important source of iron. Consumers also appreciate chicken meat due to low price, convenient portions and freedom from religious taboos (Jaturasitha et al., 2004). Genotype (breed and strain) plays a major role in carcass characteristics and meat quality (Jaturasitha et al., 2004; Shahin et al., 2005; Chaosap et al., 2006). Despite the abundant availability of cross breed broiler strains, a group of Indian consumers have acquired preference for taste and healthfulness of native chickens. Among all native chicken breeds Kadaknath, Aseel and Vanraja have their own importance. Aseel breed is known for greater robustness, disease resistance and well adaptability to local environment and is also popular for its higher body weight, vigor, alertness and fighting behavior. Vanaraja, a dual purpose chicken has become popular among the rural people as a breed used for 
income generating activity especially for the rural women (Niranjan et al., 2008). Kadaknath is local breed of Madhya Pradesh and popularly known as "Kali Masi". It is popular for adaptability and well tasting black meat which is believed to infuse vigour. As a broiler bird, Cobb 400 is fast growing, more meat yielding, feed efficient and early marketable.

Chicken by-products are eaten widely due to their low cost, low fat content and the short period of time needed in preparation. Majority of by-products offer a range of foods which are nutritionally attractive, with high protein content and good nutritional properties due to the presence of many essential nutrients and have a wide variety of flavours and textures. Poultry giblets of individual birds may be packed together with the carcass for sale, or the individual tissues retained for further processing or retail sale (Gill, 1988). The available scientific literature mainly describes sensory, technological and nutritional quality of meat, but little information is available for edible offal, or giblets. So the study was conducted to determine the nutritional and compositional values of giblets of indigenous chicken breeds like Aseel, Vanraja, Kadaknath and these values were compared with Cobb400, a broiler strain.

\section{Materials and Methods}

Birds six weeks of age from three indigenous breeds (Aseel, Vanraja, and Kadaknath" and a commercial strain (Cobb-400) that were being reared in a deep litter system were selected for study. Six birds of each breed and strain of pooled sex was used for study. Birds were sacrificed using halal slaughter procedure. Giblets were collected and processed as per standard procedure. Each and every measurement was taken using digital measurement twice for every reading. Moisture content was determined by ovendrying at $105^{\circ} \mathrm{C}$ to constant mass as described in ISO (1997). Protein content was determined according to Kjeldhal method; a factor 6.25 was used for conversion from total nitrogen to crude protein as described in ISO (1978). Total fat content was determined by solvent extraction as per ISO (1973). Total ash content was determined by combustion of the sample at $550^{\circ} \mathrm{C}$ for $8 \mathrm{~h}$ as per ISO (1998). Hot carcass weight means the weight of giblets or carcass taken immediately after slaughter. However, cold carcass weight was measured after carcasses and giblets were exposed to air under package in refrigeration temperature $\left(5 \pm 2^{0} \mathrm{C}\right)$ for atleast 24 hours. Statistical analysis was carried out using SPSS-16 software for one way and two ANOVA and level of significance was measured using DUNCAN test following the procedure of Snedecor and Cochran (1994).

\section{Results and Discussion}

Live weight and carcass weight: Live weight and carcass weight of chicken breeds/strain like Cobb-400, Vanraja, Aseel and Kadaknath are presented in table 1. All weights were measured in gram and percent were calculated on live weight basis. The live weights of indigenous breeds were in the range of $375.01 \pm 11.69$ (Kadaknath) to $472.00 \pm 17.53$ (Aseel) while Cobb-400 weight was 876.00 \pm 26.82 . Among all studied chicken, Cobb-400 had significantly higher weight than all indigenous breeds. In indigenous breeds Aseel was showing significantly $(\mathrm{P}<0.05)$ higher weight than Vanraja and Kadaknath which were no significantly different with each other.

Hot carcass weight of Aseel was significantly $(\mathrm{P}<0.05)$ higher than Vanraja and Kadaknath. However, hot carcass weights of Vanraja and Kadaknath were not significantly different. The control (Cobb-400) hot carcass weight was significantly $(\mathrm{P}<0.05)$ higher than all studied indigenous chicken breeds. The range of hot carcass weight in indigenous breeds 
was from 230.96 \pm 4.62 (Kadaknath) to $292.55 \pm 5.59$ (Aseel) while in Cobb-400 570.68 \pm 5.59 . Percent hot carcass weight in indigenous breeds was not significantly different from each other and observed range was 60.44 \pm 0.54 (Vanraja) to $61.97 \pm 0.89$ (Aseel). Overall percent hot carcass yield in Cobb-400 was significantly greater $(65.13 \pm 1.14)$ than other breeds. However, hot carcass weight of Kadaknath was in medium range.

The cold carcass weight of Cobb-400 was significantly $(\mathrm{P}<0.05)$ greater than those of all indigenous breeds. Among indigenous breeds Aseel had significantly $(\mathrm{P}<0.05)$ higher weight than Vanraja and Kadaknath which were not significantly different with each other. Percent values of cold carcass weight did not differ significantly among breeds. However, highest percent cold carcass weight was noticed in Aseel and lowest in Kadaknath. The cold carcass weight of Vanraja was next to Aseel and Cobb-400.

Overall the weight of carcasses on live and carcasses weight basis showed the respective characteristics of the breeds. The commercial strain (Cobb-400) showed highest carcass weight because it was a fast growing strain and particularly meant for the broiler production and higher weight gain. The similar pattern was reported by Debata et al. (2012) and Kgwatalala et al. (2013) on carcass weight of commercial breeds like Black Rock, Red Cornish and Vanaraja breed of chicken.

Giblet weight: The giblet weights were measured in gram and respective percent of giblet was calculated on live weight basis and data are shown in Table 1. Hot giblet weight among indigenous breeds was in range of $21.30 \pm 1.01$ (Kadaknath) to $28.65 \pm 1.25$ (Aseel) but highest weight was recorded in Cobb-400 and Vanraja was having medium weight. Hot giblet weights of studied chicken breeds/strain were significantly $(\mathrm{P}<0.05)$ different from each other but percent wise no significant differences were observed in these breeds/strain. Among all chicken, percent hot giblet weight was recorded highest in Aseel and lowest in Kadaknath. The observed cold giblet weight from highest to lowest was as Cobb-400>Aseel >Vanraja>Kadaknath. Cold giblet weight wise all breeds/strain showed significant $(\mathrm{P}<0.05)$ differences among each other while percent wise indigenous breeds were differ significantly $(\mathrm{P}<0.05)$ but Cobb400 and Kadaknath were having no significant difference. The pattern of percent cold giblet weight from highest to lowest was as Vanraja $>$ Aseel $>$ Cobb-400 $>$ Kadaknath. Hot and cold giblet percentage in respect to live weight was in the range of $5.68 \pm 0.20$ to $6.07 \pm 0.47$ and $5.47 \pm 0.10$ to $6.03 \pm 0.80$ respectively. These findings were very well matched with the findings reported by Kgwatalala et al. (2013), Ockerman et al. (2000), Daros et al. (2005) and Spooncer (1988) in different poultry species. Overall they reported the yield of edible by-products for chickens was from 5 to 6 percent of the live weight. Somsen et al. (2004) also reported the average yield of the chicken giblets (heart, liver and gizzard) at an average live weight prior to slaughtering of $1898 \mathrm{~g}$ was $4.36 \%$.

\section{Individual giblet values on live weight basis}

Individual hot and cold organ percent calculated on live weight and total giblet weight are presented in table 2 .

Heart: Aseel was showing highest percent hot heart weight on live weight among all studied chicken whereas, lowest was observed in Kadaknath. Vanraja and Cobb-400 heart values were in medium range. In indigenous breeds Aseel and Kadaknath as well as Vanraja and Kadaknath was showing significant $(\mathrm{P}<0.05)$ differences in between while no significant differences were noticed in between hot heart percent of Vanraja and Aseel. Overall Aseel and Kadaknath showed 
significantly $(\mathrm{P}<0.05)$ higher heart values than Cobb-400 while no significant difference was observed between Cobb-400 and Vanraja.

On cold weight basis, highest heart percent was recorded in Aseel followed by Vanraja, Cobb-400 and Kadaknath. Vanraja and Aseel cold heart weight did not show any significant differences from each other while these values were significantly $(\mathrm{P}<0.05)$ higher from Kadaknath. Overall significantly $(\mathrm{P}<0.05)$ higher heart weight was noticed in Vanraja and Aseel than the values reported for Cobb400.

Liver: The overall range of hot liver weight in respect to live weight was $2.67 \pm 0.13$ (Kadaknath) to $3.23 \pm 0.11$ (Vanraja). The percent hot liver weight of Aseel was higher than Kadaknath but lower than Vanraja and Cobb-400. Hot liver weight among indigenous chicken breeds revealed significantly $(\mathrm{P}<0.05)$ higher weight in Vanraja than other breeds. However, hot liver percent weight of Kadaknath and Aseel was not significantly $(\mathrm{P}<0.05)$ different from each other. Overall significant $(\mathrm{P}<0.05)$ difference was observed in between Cobb-400 and Kadaknath while no significant differences were observed among Cobb-400, Vanraja and Aseel.

On cold weight basis, liver percent value was highest in Vanraja followed by Cobb-400, Aseel and Kadaknath. In indigenous breeds, significantly $(\mathrm{P}<0.05)$ higher cold liver weight was recorded in Vanraja than Aseel and Kadaknath which were not significantly different with each other. However, on overall basis, Cobb-400 liver value was comparable to the values noticed in all indigenous breeds.

Gizzard: Percent hot gizzard weight among various chicken breeds/strain calculated on live weight was in the range of $2.16 \pm 0.12$ to $2.59 \pm 0.03$. The highest values were recorded in Cobb-400 and lowest in Kadaknath while Vanraja and Aseel had medium range. Among indigenous breeds, Vanraja was showing significantly $(\mathrm{P}<0.05)$ lower gizzard weight than Aseel and Kadaknath which were not showing significant $(\mathrm{P}<0.05)$ difference with each other. Overall hot gizzard percent weight of Cobb-400 was significantly $(\mathrm{P}<0.05)$ lower than Aseel and Kadaknath but no significant difference was observed with Vanraja.

On cold weight basis, gizzard values were in increasing order as Cobb-400>Vanraja>Aseel $>$ Kadaknath. Indigenous breeds did not have significant differences among each other but Cobb-400 value was significantly $(\mathrm{P}<0.05)$ lower than Aseel and Kadaknath. However, no significant difference was observed in cold gizzard weight between Cobb-400 and Vanraja.

The ratio of heart, liver and gizzard in indigenous breeds and Cobb-400 on live weight basis reported in this study was supported by the study of Olawumi et al. (2012). They reported a pattern of the values of heart, liver and gizzard in the proportion of 10.8,45.4, $45.4 \mathrm{~g}$ in Marshall, 10.8, 42.2, 44.8 $\mathrm{g}$ in Hubbard and 9.8,41.4, 45.2 $\mathrm{g}$ in Arbor Acre chicken breeds. The pattern reported in the study was almost similar however; gizzard weight shown in the study was higher to liver weight. The findings of present study were also supported with the study of Tazi et al. (2014).

\section{Individual giblet values on total giblet weight basis}

Heart: On total giblet weight basis, percent hot heart weight showed the decreasing order as Vanraja>Aseel $>$ Cobb-400 >Kadaknath. In indigenous breeds significant $(\mathrm{P}<0.05)$ differences were observed but percent hot heart weight of Cobb-400 was significantly $(\mathrm{P}<0.05)$ lower than Vanraja and higher than Kadaknath. However, no significant difference was observed between Aseel and Cobb-400. 
On cold giblet weight basis, percent heart weight from higher to lower was as Vanraja>Aseel $>$ Cobb-400 >Kadaknath. The level of significance was also showing same pattern as in hot heart weight among indigenous breeds as well as with Cobb-400 and indigenous breeds.

Liver: Percent hot liver weight on total giblet weight basis in decreasing order was as Cobb400>Vanraja>Aseel >Kadaknath. In indigenous breeds liver weight of Vanraja was significantly $(\mathrm{P}<0.05)$ higher than Aseel and Kadaknath which were not significantly different with each other. However, hot liver weight of Cobb-400 in relation to indigenous breeds showed significant $(\mathrm{P}<0.05)$ difference from all indigenous chicken breeds. The percent cold liver weight on total giblet weight basis reflected the values from higher to lower as Cobb-400>Vanraja>Aseel>Kadaknath. The level of significance showed similar pattern as found in hot liver weight.

Gizzard: The order of increase percent hot gizzard weight when calculated on total giblet basis was as Cobb-400 >Vanraja >Aseel > Kadaknath. In indigenous breeds significant $(\mathrm{P}<0.05)$ differences were observed in hot gizzard weight among indigenous breeds. The hot gizzard weight of Cobb-400 showed no significant difference with Vanraja and significantly $(\mathrm{P}<0.05)$ lower weight from Aseel and Kadaknath.

The values recorded for cold gizzard weight on total giblet weight revealed the values in order of increase as Cobb400 > Vanraja $>$ Aseel $>$ Kadaknath. Indigenous chicken breeds showed significant $(\mathrm{P}<0.05)$ differences among each other for cold gizzard wight. However, percent value of cold gizzard for Cobb-400 was found significantly $(\mathrm{P}<0.05)$ lower than Aseel and Kadaknath but no significant difference was noticed from Vanraja.

\section{Individual giblet values on carcass weight basis}

The percent hot and cold giblet weight values obtained on carcass weight for indigenous chicken breeds i.e. Vanraja, Aseel and Kadaknath and Cobb-400 are given in figure 1 and 2.

\section{Based on hot carcass weight}

Heart: Percent hot heart weight calculated on carcass weight basis showed decreasing pattern as Aseel $>$ Vanraja $>$ Cobb-400 $>$ Kadaknath. In indigenous chicken breeds heart weight showed significantly $(\mathrm{P}<0.05)$ lower values in Kadaknath than Vanraja and Aseel which were not significantly different from each other. However, significant $(\mathrm{P}<0.05)$ difference was noticed in hot heart weight of Cobb-400 than all indigenous breeds.

Liver: The pattern of decrease in percent hot liver weight was as Vanraja>Cobb-400>Aseel $>$ Kadaknath. The heart weight values of indigenous breeds showed significantly $(\mathrm{P}<0.05)$ higher weight in Vanraja than Aseel and Kadaknath while Aseel and kadaknath values were non significantly different from each other. However, the liver weight of Cobb-400 with comparison to indigenous chicken significantly $(\mathrm{P}<0.05)$ different from Vanraja but no significant differences were observed from Aseel and Kadaknath.

Gizzard: The hot gizzard weight values in increasing order was as Cobb400>Vanraja>Aseel $>$ Kadaknath. Among indigenous breeds, gizzard weight of Vanraja was significantly $(\mathrm{P}<0.05)$ lower percent than Aseel and Kadaknath while latter two breeds did not differ significantly with each other. However, the percent hot gizzard weight of Cobb-400 was significantly $(\mathrm{P}<0.05)$ different with all indigenous breeds. 
Total giblet: The percent total giblets weights on hot carcass basis were in order of decrease as Vanraja>Aseel >Kadaknath> Cobb-400. In indigenous breeds, Kadaknath showed significantly $(\mathrm{P}<0.05)$ lower values than Vanraja and Aseel which were not significantly different from each other. However, total giblets of Cobb-400 on hot carcass weight was significantly $(\mathrm{P}<0.05)$ different from Vanraja and Aseel but not significantly from Kadaknath.

\section{Based on cold carcass weight:}

Heart: The pattern of decreasing cold heart weight was as Aseel $>$ Vanraja $>$ Cobb400>Kadaknath. In indigenous chicken breeds, Kadaknath was having significantly $(\mathrm{P}<0.05)$ lower cold heart weight than Vanraja and Aseel while latter two did not differ significantly with each other. Overall Cobb400 was significantly $(\mathrm{P}<0.05)$ different from the heart values of Aseel and Kadaknath but not with Vanraja.

Liver: The decreasing pattern of cold liver weight was as Vanraja $>$ Cobb400>Aseel $>$ Kadaknath. Vanraja liver value was found significantly $(\mathrm{P}<0.05)$ higher than Aseel and Kadaknath which were no significantly different with each other. Cold liver weight of Cobb-400 revealed significantly $(\mathrm{P}<0.05)$ lower weight from Vanraja and higher than Kadaknath but no significant difference was observed with Aseel.

Gizzard: The increasing order of cold gizzard weights was recorded as Cobb400>Vanraja>Aseel> Kadaknath. Among indigenous breeds gizzard value of Kadaknath was significantly $(\mathrm{P}<0.05)$ higher than Vanraja and Aseel while latter two breeds did not show significant differences with each other. Cobb-400 values for gizzard were significantly $\quad(\mathrm{P}<0.05) \quad$ lower than all indigenous breeds.
Total giblet: The pattern of decreasing cold total giblet weight was Vanraja>Aseel> Kadaknath $>$ Cobb-400. Indigenous breeds revealed significantly $(\mathrm{P}<0.05)$ higher values in Vanraja than Aseel and Kadaknath which were not significantly different from each other. Overall significantly $(\mathrm{P}<0.05)$ lower giblet value was in Cobb-400 than Vanraja but no significant differences were observed from Aseel and Kadaknath.

\section{Compositional characteristics of giblets}

Giblets were also evaluated for moisture, fat, protein and ash contents as compositional characteristics and presented in table 3.

Heart: Heart moisture content was highest in Kadaknath and lowest in Cobb-400 while Vanraja and Aseel showed medium range. Overall significant $(\mathrm{P}<0.05)$ differences were observed in moisture values of various breeds of chicken except the values reported in between Vanraja and Aseel. Overall fat content range was $7.39 \pm 0.54$ to $12.36 \pm 0.22$. Kadaknath showed lowest and Cobb-400 had highest fat values. Fat content in Vanraja and Aseel were in medium range. Studied chicken breeds/strain were having significant $(\mathrm{P}<0.05)$ differences in fat values among each other except the fat values of Vanraja and Aseel which were not significantly different.

The decreasing order of protein was as Cobb400>Aseel> Vanraja >Kadaknath. Overall protein content in heart of different indigenous chicken were not significantly $(\mathrm{P}>0.05)$ different among each other except Cobb-400 and Kadaknath giblets which were having significant $(\mathrm{P}<0.05)$ values with each other. The ash content pattern from highest to lowest was Vanraja > Cobb-400 > Aseel > Kadaknath. Ash contents in indigenous chicken heart revealed significant $(\mathrm{P}<0.05)$ differences among each. However, Cobb-400 did not differ from Vanraja and Aseel while 
significantly $(\mathrm{P}<0.05)$ lower ash content was recorded in Kadakanth than Cobb-400.

Liver: The liver of Cobb-400 overall showed highest moisture content followed by Aseel, Kadaknath and Vanraja in decreasing order. Overall significantly $(\mathrm{P}<0.05)$ different moisture content was recorded in Cobb-400, Vanraja and Aseel but Kadaknath showed comparable values with Vanraja and Aseel. The fat content in Vanraja liver was highest while lowest fat value was reported in Kadaknath liver. The fat value in Aseel was next highest to Vanraja while Cobb-400 had lowest to the Kadaknath.

In indigenous chicken, significantly $(\mathrm{P}<0.05)$ different fat values were noticed among each other. However, Cobb-400 showed significantly $(\mathrm{P}<0.05)$ lower fat values than Vanraja and Kadaknath while no significant difference was noticed with Aseel. The trend of protein from lowest to highest was Cobb400>Aseel> Vanraja > Kadaknath). In protein contents of indigenous breeds, Kadaknath showed significantly $(\mathrm{P}<0.05)$ higher value than Vanraja and Aseel while were not significantly different from each other.

However, protein in liver of Cobb-400 showed significantly $(\mathrm{P}<0.05)$ lower values than all indigenous breeds. Ash content in liver of studied chicken breeds revealed increasing trend from Cobb-400>Kadaknath>Vanraja > Aseel. Indigenous breeds of chicken did not show any significant differences in ash content among each other while Cobb-400 had significantly $(\mathrm{P}<0.05)$ lower value than Vanraja and Aseel.

Gizzard: Overall Cobb-400 had highest moisture percent in gizzards followed by Vanraja, Aseel and Kadaknath in decreasing order. In indigenous breeds, Kadaknath was having significantly $(\mathrm{P}<0.05)$ lower moisture values than Vanraja and Aseel which were not different. Cobb-400 had significantly $(\mathrm{P}<0.05)$ higher moisture values than all indigenous breeds. Gizzard fat content was lowest in Kadaknath, highest in Cobb-400 and intermediate in Vanraja and Aseel. The contents of protein in gizzards were in increasing order as Cobb-400> Vanraja> Aseel $>$ Kadaknath. Protein content was significantly $(\mathrm{P}<0.05)$ different among all studied chicken breeds. The pattern of ash content in gizzard from highest to lowest was as Cobb-400>Vanraja $>$ Aseel $>$ Kadaknath. Gizzard ash of Cobb-400 was significantly $(\mathrm{P}<0.05)$ higher than all indigenous breeds. Among which Aseel was having comparable values to Vanraja and Kadaknath.

Total Giblet: Heart, liver and gizzard jointly make giblet. Overall giblet of Cobb-400 had highest moisture content and Aseel accounts lowest. Overall no significant differences were observed in moisture contents of giblet in various chicken breeds/strain. Fat content in giblets of studied breeds ranges from $5.01 \pm 0.49$ to $6.94 \pm 0.96$ percent. Highest estimated fat content was in Cobb-400 and lowest in Kadaknath. The values of fat among various chicken breeds/strain also did not show any significant differences.

The percent protein values in giblets of different chicken breeds estimated from lowest to highest as Cobb400>Vanraja>Aseel> Kadaknath. No significant differences were noticed in protein contents among various indigenous breeds. But Cobb-400 had significantly $(\mathrm{P}<0.05)$ lower protein values than Aseel and Kadaknath while comparable value with Vanraja.

The pattern of ash values estimated in the giblets was Cobb-400=Vanraja $<$ Aseel $<$ Kadaknath. Ash values among all chicken revealed significantly $(\mathrm{P}>0.05)$ lower values in Kadaknath than Vanraja and Aseel was well as with Cobb-400 while latter breeds did not have significant differences with each other. 
Table.1 Carcass and giblets yields (Mean \pm SE) on live weight as well as on giblet weight basis $(\mathrm{n}=12)$

\begin{tabular}{|l|l|l|l|l|}
\hline \multirow{2}{*}{$\begin{array}{l}\text { Carcass and Giblet } \\
\text { traits }\end{array}$} & \multicolumn{4}{|c|}{ Breeds/Strain } \\
\cline { 2 - 5 } & Cobb-400 & Vanraja & Aseel & Kadaknath \\
\hline Live weight $(\mathrm{g})$ & $876.00^{\mathrm{a}} \pm 26.82$ & $392.34^{\mathrm{c}} \pm 12.90$ & $472.00^{\mathrm{b}} \pm 17.53$ & $375.01^{\mathrm{c}} \pm 11.69$ \\
\hline Hot carcass weight $(\mathrm{g})$ & $570.68^{\mathrm{a}} \pm 11.54$ & $237.14^{\mathrm{c}} \pm 7.97$ & $292.55^{\mathrm{b}} \pm 2.59$ & $230.96^{\mathrm{c}} \pm 4.62$ \\
\hline Hot carcass weight $(\%)$ & $65.13^{\mathrm{a}} \pm 1.14$ & $60.44^{\mathrm{b}} \pm 0.54$ & $61.97^{\mathrm{b}} \pm 0.89$ & $61.59^{\mathrm{b}} \pm 0.57$ \\
\hline Cold carcass weight $(\mathrm{g})$ & $511.01^{\mathrm{a}} \pm 7.88$ & $228.21^{\mathrm{c}} \pm 4.68$ & $278.21^{\mathrm{b}} \pm 8.26$ & $215.86^{\mathrm{c}} \pm 2.79$ \\
\hline Cold carcass weight $(\%)$ & $58.33 \pm 1.87$ & $58.16 \pm 1.54$ & $58.94 \pm 1.74$ & $57.56 \pm 1.24$ \\
\hline Hot giblet weight $(\mathrm{g})$ & $50.45^{\mathrm{a}} \pm 1.37$ & $23.74^{\mathrm{c}} \pm 1.03$ & $28.65^{\mathrm{b}} \pm 1.25$ & $21.30^{\mathrm{d}} \pm 1.01$ \\
\hline Hot giblet weight $(\%)$ & $5.76 \pm 0.19$ & $6.05 \pm 0.35$ & $6.07 \pm 0.47$ & $5.68 \pm 0.20$ \\
\hline Cold giblet weight $(\mathrm{g})$ & $48.00^{\mathrm{a}} \pm 2.39$ & $23.66^{\mathrm{c}} \pm 1.57$ & $27.28^{\mathrm{b}} \pm 1.90$ & $20.51^{\mathrm{d}} \pm 1.88$ \\
\hline Cold giblet weight $(\%)$ & $5.48^{\mathrm{c}} \pm 0.28$ & $6.03^{\mathrm{a}} \pm 0.80$ & $5.78^{\mathrm{b}} \pm 0.18$ & $5.47^{\mathrm{c}} \pm 0.10$ \\
\hline
\end{tabular}

- Means bearing different superscripts $(\mathrm{a}, \mathrm{b}, \mathrm{c}, \mathrm{d})$ within row differ significantly $(\mathrm{P}<0.05)$

Table.2 Individual giblet (heart, liver and gizzard) values (Mean \pm SE) on live weight and giblet percent basis $(n=6)$

\begin{tabular}{|l|l|l|l|l|l|l|l|l|}
\hline \multirow{2}{*}{ Giblet $(\%)$} & \multicolumn{9}{|c|}{ On Live weight basis } & \multicolumn{4}{c|}{ On Giblet weight basis } \\
\cline { 2 - 9 } & Cobb-400 & Vanraja & Aseel & Kadaknath & Cobb-400 & \multicolumn{1}{l|}{ Vanraja } & Aseel & Kadaknath \\
\hline On hot weight basis & $0.56^{\mathrm{b}} \pm 0.02$ & $0.61^{\mathrm{ab}} \pm 0.01$ & $0.67^{\mathrm{a}} \pm 0.02$ & $0.42^{\mathrm{c}} \pm 0.01$ & $9.63^{\mathrm{b}} \pm 0.15$ & $11.39^{\mathrm{a}} \pm 0.16$ & $10.04^{\mathrm{b}} \pm 0.24$ & $7.58^{\mathrm{c}} \pm 0.15$ \\
\hline Heart & $3.04^{\mathrm{ab}} \pm 0.05$ & $3.23^{\mathrm{a}} \pm 0.11$ & $2.83^{\mathrm{bc}} \pm 0.11$ & $2.67^{\mathrm{c}} \pm 0.13$ & $53.28^{\mathrm{a}} \pm 0.77$ & $51.36^{\mathrm{b}} \pm 0.29$ & $47.79^{\mathrm{c}} \pm 0.42$ & $46.82^{\mathrm{c}} \pm 0.63$ \\
\hline Liver & $2.16^{\mathrm{b}} \pm 0.12$ & $2.21^{\mathrm{b}} \pm 0.09$ & $2.57^{\mathrm{a}} \pm 0.11$ & $2.59^{\mathrm{a}} \pm 0.03$ & $37.10^{\mathrm{c}} \pm 1.24$ & $37.22^{\mathrm{c}} \pm 0.30$ & $42.16^{\mathrm{b}} \pm 1.07$ & $45.59^{\mathrm{a}} \pm 0.67$ \\
\hline Gizzard & $0.53^{\mathrm{b}} \pm 0.02$ & $0.60^{\mathrm{a}} \pm 0.01$ & $0.63^{\mathrm{a}} \pm 0.02$ & $0.39^{\mathrm{c}} \pm 0.02$ & $9.62^{\mathrm{b}} \pm 0.15$ & $11.05^{\mathrm{a}} \pm 0.17$ & $9.99^{\mathrm{b}} \pm 0.24$ & $7.41^{\mathrm{c}} \pm 0.15$ \\
\hline On cold weight basis & $2.90^{\mathrm{ab}} \pm 0.05$ & $3.21^{\mathrm{a}} \pm 0.11$ & $2.80^{\mathrm{b}} \pm 0.11$ & $2.58^{\mathrm{b}} \pm 0.13$ & $53.08^{\mathrm{a}} \pm 0.75$ & $50.59^{\mathrm{b}} \pm 0.31$ & $47.14^{\mathrm{c}} \pm 0.43$ & $46.21^{\mathrm{c}} \pm 0.63$ \\
\hline Heart & $2.04^{\mathrm{b}} \pm 0.12$ & $2.22^{\mathrm{ab}} \pm 0.08$ & $2.35^{\mathrm{a}} \pm 0.11$ & $2.50^{\mathrm{a}} \pm 0.03$ & $36.23^{\mathrm{b}} \pm 1.25$ & $37.69^{\mathrm{b}} \pm 0.30$ & $42.41^{\mathrm{a}} \pm 1.07$ & $42.83^{\mathrm{a}} \pm 0.78$ \\
\hline Liver &
\end{tabular}

- Means bearing different superscripts $(\mathrm{a}, \mathrm{b}, \mathrm{c}, \mathrm{d})$ within row differ significantly $(\mathrm{P}<0.05)$ 
Table.3 Compositional quality values ((Mean \pm SE) of indigenous chicken giblets $(n=6)$

\begin{tabular}{|l|l|l|l|l|l|}
\hline Giblets & $\begin{array}{l}\text { Compositional } \\
\text { parameters }\end{array}$ & \multicolumn{5}{|c|}{ Poultry breeds } \\
\cline { 3 - 6 } & & Cobb-400 & Vanraja & Aseel & Kadaknath \\
\hline \multirow{4}{*}{ Heart } & Moisture & $71.74^{\mathrm{c}} \pm 0.43$ & $74.15^{\mathrm{b}} \pm 0.34$ & $73.60^{\mathrm{b}} \pm 0.44$ & $77.87^{\mathrm{a}} \pm 0.72$ \\
\cline { 2 - 6 } & Fat & $12.36^{\mathrm{a}} \pm 0.22$ & $10.45^{\mathrm{b}} \pm 0.13$ & $10.94^{\mathrm{b}} \pm 0.25$ & $7.39^{\mathrm{c}} \pm 0.54$ \\
\cline { 2 - 6 } & Protein & $12.37^{\mathrm{a}} \pm 0.20$ & $11.94^{\mathrm{ab}} \pm 0.27$ & $12.03^{\mathrm{ab}} \pm 0.24$ & $11.60^{\mathrm{b}} \pm 0.19$ \\
\cline { 2 - 6 } & Ash & $0.87^{\mathrm{ab}} \pm 0.005$ & $0.91^{\mathrm{a}} \pm 0.012$ & $0.85^{\mathrm{b}} \pm 0.019$ & $0.48^{\mathrm{c}} \pm 0.027$ \\
\hline \multirow{5}{*}{ Liver } & Moisture & $76.11^{\mathrm{a}} \pm 0.39$ & $72.12^{\mathrm{c}} \pm 0.17$ & $73.02^{\mathrm{b}} \pm 0.25$ & $72.48^{\mathrm{bc}} \pm 0.05$ \\
\cline { 2 - 6 } & Fat & $5.37^{\mathrm{b}} \pm 0.12$ & $5.97^{\mathrm{a}} \pm 0.02$ & $5.52^{\mathrm{b}} \pm 0.12$ & $4.89^{\mathrm{c}} \pm 0.11$ \\
\cline { 2 - 6 } & Protein & $15.20^{\mathrm{c}} \pm 0.20$ & $18.16^{\mathrm{b}} \pm 0.27$ & $17.93^{\mathrm{b}} \pm 0.24$ & $19.02^{\mathrm{a}} \pm 0.19$ \\
\hline \multirow{5}{*}{ Gizzard } & Ash & $0.97^{\mathrm{b}} \pm 0.020$ & $1.02^{\mathrm{a}} \pm 0.015$ & $1.04^{\mathrm{a}} \pm 0.018$ & $1.00^{\mathrm{ab}} \pm 0.008$ \\
& Moisture & $78.75^{\mathrm{a}} \pm 0.25$ & $76.47^{\mathrm{b}} \pm 0.26$ & $75.82^{\mathrm{b}} \pm 0.21$ & $74.75^{\mathrm{c}} \pm 0.30$ \\
\cline { 2 - 6 } & Fat & $3.10 \pm 0.22$ & $2.88 \pm 0.10$ & $2.93 \pm 0.05$ & $2.74 \pm 0.11$ \\
\cline { 2 - 6 } & Protein & $14.13^{\mathrm{d}} \pm 0.08$ & $17.17^{\mathrm{c}} \pm 0.09$ & $17.85^{\mathrm{b}} \pm 0.05$ & $19.23^{\mathrm{a}} \pm 0.15$ \\
\cline { 2 - 6 } & Ash & $1.05^{\mathrm{a}} \pm 0.018$ & $0.96^{\mathrm{b}} \pm 0.014$ & $0.91^{\mathrm{bc}} \pm 0.015$ & $0.81^{\mathrm{c}} \pm 0.059$ \\
\hline Giblets & Moisture & $75.53 \pm 0.72$ & $74.25 \pm 0.45$ & $74.15 \pm 0.34$ & $75.03 \pm 0.58$ \\
\hline & Fat & $6.94 \pm 0.96$ & $6.43 \pm 0.75$ & $6.46 \pm 0.81$ & $5.01 \pm 0.49$ \\
\hline & Protein & $13.90^{\mathrm{b}} \pm 0.30$ & $15.75^{\mathrm{ab}} \pm 0.66$ & $15.93^{\mathrm{a}} \pm 0.68$ & $16.62^{\mathrm{a}} \pm 0.86$ \\
\hline & Ash & $0.96^{\mathrm{a}} \pm 0.02$ & $0.96^{\mathrm{a}} \pm 0.01$ & $0.93^{\mathrm{a}} \pm 0.02$ & $0.76^{\mathrm{b}} \pm 0.05$ \\
\hline
\end{tabular}

- Means bearing different superscripts $(\mathrm{a}, \mathrm{b}, \mathrm{c}, \mathrm{d})$ within row differ significantly $(\mathrm{P}<0.05)$ 
Table.4 Mineral profile (mg/kg) in indigenous breeds of chicken giblets $(n=6)$

\begin{tabular}{|l|l|l|l|l|l|}
\hline \multirow{5}{*}{ Giblets } & $\begin{array}{l}\text { Minerals } \\
(\mathbf{m g} / \mathbf{k g})\end{array}$ & \multicolumn{4}{|c|}{ Poultry breeds } \\
\cline { 2 - 6 } & & Cobb-400 & Vanraja & Aseel & Kadaknath \\
\hline \multirow{5}{*}{ Heart } & $\mathrm{Na}$ & $2213.30^{\mathrm{a}} \pm 14.52$ & $2211.30^{\mathrm{a}} \pm 13.29$ & $2185.00^{\mathrm{a}} \pm 3.60$ & $1780.00^{\mathrm{b}} \pm 29.56$ \\
\cline { 2 - 6 } & $\mathrm{K}$ & $1150.30^{\mathrm{b}} \pm 3.84$ & $1202.30^{\mathrm{a}} \pm 6.76$ & $1092.70^{\mathrm{c}} \pm 6.83$ & $918.00^{\mathrm{d}} \pm 4.04$ \\
\cline { 2 - 6 } & $\mathrm{Fe}$ & $31.58^{\mathrm{c}} \pm 0.35$ & $65.06^{\mathrm{a}} \pm 0.03$ & $32.24^{\mathrm{c}} \pm 0.22$ & $35.53^{\mathrm{b}} \pm 0.26$ \\
\cline { 2 - 6 } & $\mathrm{Zn}$ & $18.58^{\mathrm{b}} \pm 0.07$ & $54.60^{\mathrm{a}} \pm 0.30$ & $19.25^{\mathrm{b}} \pm 0.16$ & $19.07^{\mathrm{b}} \pm 0.04$ \\
\hline \multirow{5}{*}{ Liver } & $\mathrm{Na}$ & $2673.30^{\mathrm{a}} \pm 9.90$ & $2700.00^{\mathrm{a}} \pm 5.92$ & $2591.00^{\mathrm{b}} \pm 2.00$ & $2456.00^{\mathrm{c}} \pm 16.16$ \\
\cline { 2 - 6 } & $\mathrm{K}$ & $814.67^{\mathrm{b}} \pm 2.02$ & $919.00^{\mathrm{a}} \pm 10.53$ & $805.00^{\mathrm{b}} \pm 3.46$ & $800.00^{\mathrm{b}} \pm 2.88$ \\
\cline { 2 - 6 } & $\mathrm{Fe}$ & $82.63^{\mathrm{b}} \pm 0.19$ & $170.00^{\mathrm{a}} \pm 3.51$ & $84.66^{\mathrm{b}} \pm 0.20$ & $79.82^{\mathrm{b}} \pm 0.24$ \\
\hline \multirow{5}{*}{ Gizzard } & $\mathrm{Zn}$ & $24.28^{\mathrm{b}} \pm 0.55$ & $50.23^{\mathrm{a}} \pm 0.42$ & $24.68^{\mathrm{b}} \pm 0.27$ & $21.87^{\mathrm{c}} \pm 0.07$ \\
\cline { 2 - 6 } & $\mathrm{Na}$ & $1947.70^{\mathrm{a}} \pm 21.36$ & $1954.00^{\mathrm{a}} \pm 38.68$ & $1892.00^{\mathrm{a}} \pm 7.50$ & $1785.70^{\mathrm{b}} \pm 6.69$ \\
\cline { 2 - 6 } & $\mathrm{K}$ & $812.00^{\mathrm{a}} \pm 14.04$ & $819.33^{\mathrm{a}} \pm 15.60$ & $788.33^{\mathrm{a}} \pm 0.88$ & $706.67^{\mathrm{b}} \pm 3.92$ \\
\cline { 2 - 6 } & $\mathrm{Fe}$ & $19.75^{\mathrm{c}} \pm 0.12$ & $40.22^{\mathrm{a}} \pm 0.09$ & $21.35^{\mathrm{b}} \pm 0.32$ & $20.33^{\mathrm{c}} \pm 0.12$ \\
\cline { 2 - 6 } & $\mathrm{Zn}$ & $19.73^{\mathrm{c}} \pm 0.13$ & $40.23^{\mathrm{a}} \pm 0.49$ & $21.44^{\mathrm{b}} \pm 0.29$ & $20.55^{\mathrm{bc}} \pm 0.25$ \\
\hline Giblets & $\mathrm{Na}$ & $2278.10 \pm 1.06$ & $2288.60 \pm 1.10$ & $2222.70 \pm 1.01$ & $2007.20 \pm 1.12$ \\
\hline & $\mathrm{K}$ & $925.67^{\mathrm{a}} \pm 56.32$ & $980.22^{\mathrm{a}} \pm 57.65$ & $895.33^{\mathrm{ab}} \pm 49.44$ & $808.22^{\mathrm{b}} \pm 30.62$ \\
\hline & $\mathrm{Fe}$ & $44.65^{\mathrm{b}} \pm 9.64$ & $91.76^{\mathrm{a}} \pm 19.91$ & $46.08^{\mathrm{b}} \pm 9.77$ & $45.23^{\mathrm{b}} \pm 8.92$ \\
\hline & $\mathrm{Zn}$ & $20.86^{\mathrm{b}} \pm 0.88$ & $48.35^{\mathrm{a}} \pm 2.13$ & $21.79^{\mathrm{b}} \pm 0.79$ & $20.50^{\mathrm{b}} \pm 0.41$ \\
\hline
\end{tabular}

- Means bearing different superscripts $(\mathrm{a}, \mathrm{b}, \mathrm{c}, \mathrm{d})$ within row differ significantly $(\mathrm{P}<0.05)$ 
Fig.1 Giblets of indigenous chicken breeds/strain

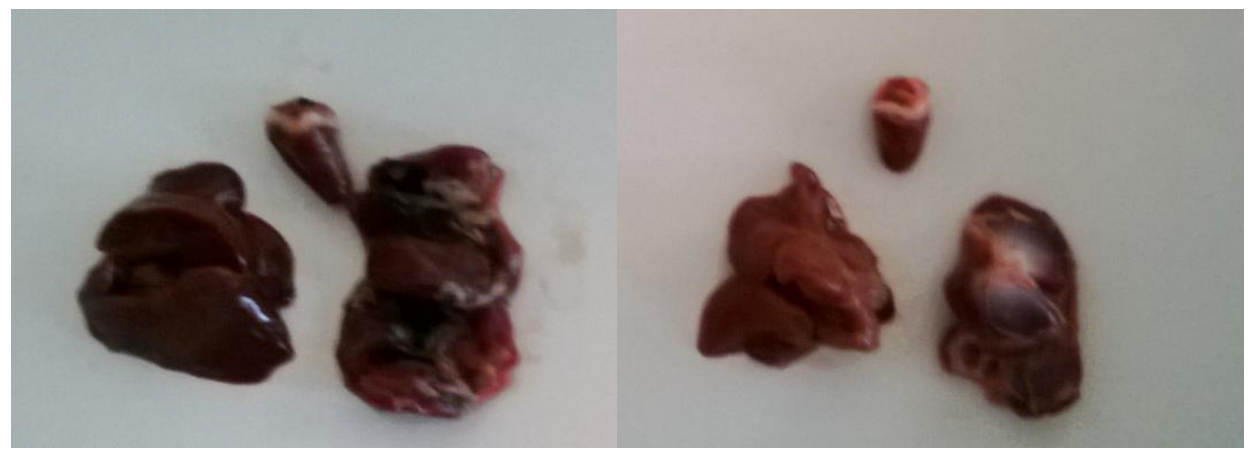

Kadaknath

Aseel

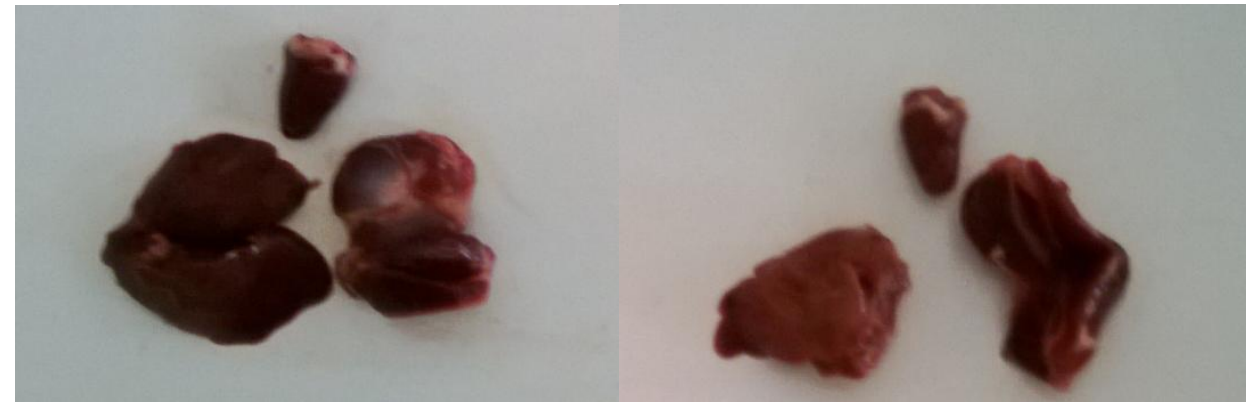

Vanraja

Cobb-400

Fig.2 Giblet of indigenous chickens on hot carcass weight basis

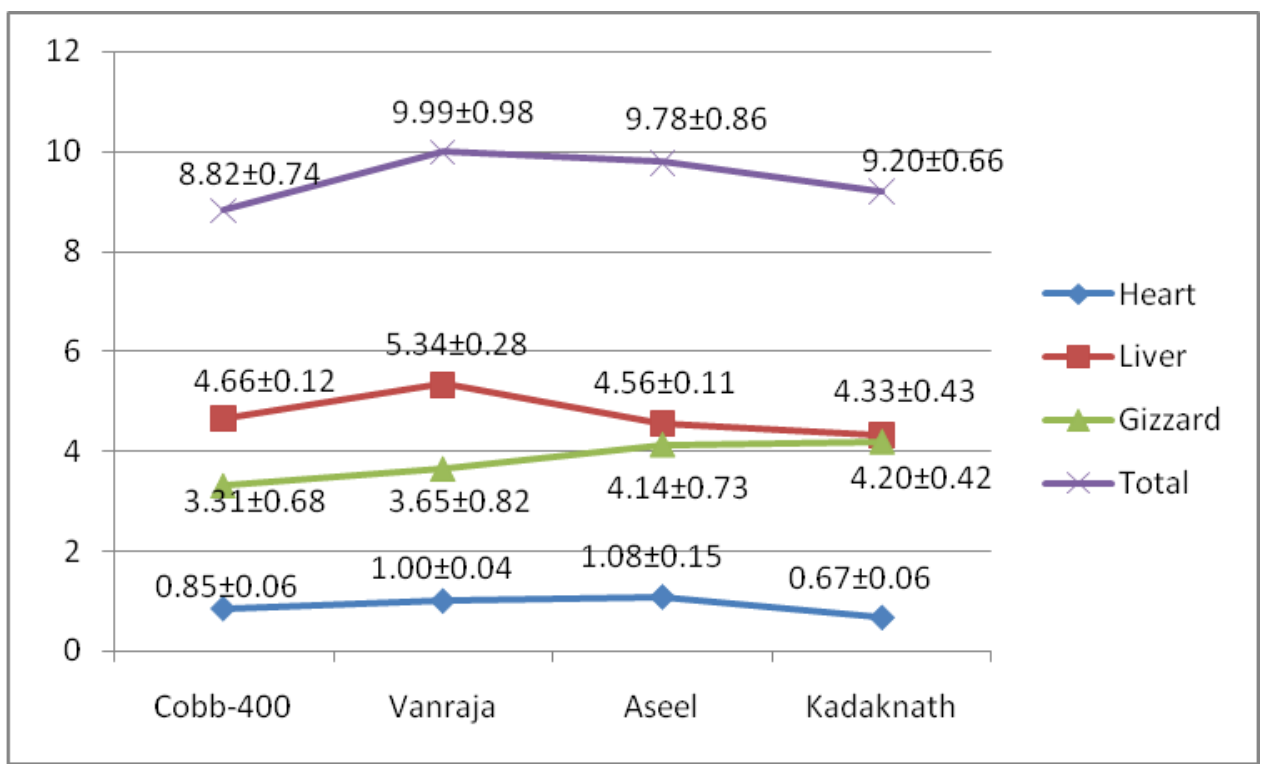


Fig.3 Giblet of indigenous chickens on cold carcass weight basis

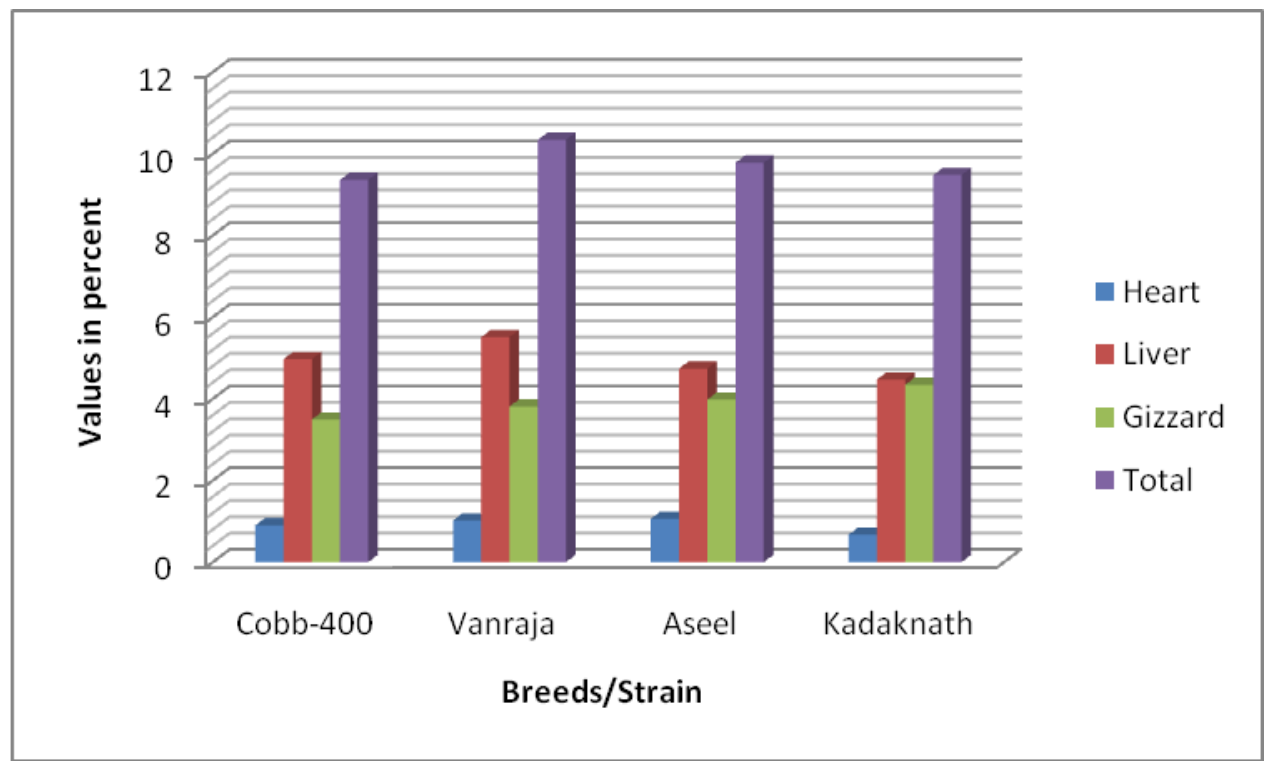

Results obtained on chemical composition of giblets of various indigenous and Cobb-400 strain of chicken showed a typical pattern, moisture percent was overall higher in the gizzard, fat in heart and protein in liver. In contrast, minimal moisture percent was reported in heart, fat in gizzard and protein in heart. Overall giblet values showed higher moisture in Cobb-400 and minimal in Aseel that might be the breed nature of the birds and might be also due to activity status of the breed. Fat contents wise maximum amount was record in Cobb-400 and minimum in Kadaknath which might also be due to genetic makeup of the breed and strain. Protein values were reported highest in Kadaknath and lowest in Cobb-400 which might also be due to genetic capability of conversion of feed into the protein. Ash content wise Kadaknath showed minimal values, whereas the rest were similar. Results obtained for protein contents in heart and gizzard were somewhat lower than results reported by Demirbas (1999) on giblets tissues of chickens from Vojvodina (North Serbia).

Results for protein content in liver were lower than reported in nutrient composition of liver in chicken by Romans et al. (1994). In the present study heart and liver were higher, while gizzard was lower in total fat content and found almost similar in findings as reported by Demirbas (1999) and Romans et al. (1994) in indigenous chicken breeds of different countries.

The Physico-chemical characteristics found in the study on giblets of various chicken breeds were very well in the range of values reported by Jokanović et al. (2014). They reported that proximate composition wise heart was the highest in total fat content, and the lowest in protein content. Liver was the highest in protein and total ash content, while gizzard was the highest in moisture and the lowest in total fat content.

\section{Mineral profile of giblets}

Giblets were also evaluated for minerals like sodium, potassium, iron and zinc and values are presented in table 4 .

Heart: The sodium content in Kadaknath heart was significantly $(\mathrm{P}<0.05)$ lower than all other chicken breeds. The contents of iron and 
potassium among various chicken breeds showed significantly $(\mathrm{P}<0.05) \quad$ different values. However, zinc content in Vanraja was showing significantly $(\mathrm{P}<0.05)$ higher values than all chicken breeds.

Liver: The contents of sodium and zinc in liver of various chicken breeds were showing significantly $(\mathrm{P}<0.05)$ different values. However, potassium and iron content in liver of Vanraja breed was significantly $(\mathrm{P}<0.05)$ higher than other breeds.

Gizzard: Sodium and potassium content in Kadaknath breed was showing significantly $(\mathrm{P}<0.05)$ lower values than other breeds. The content of iron among indigenous chicken was showing significantly $(\mathrm{P}<0.05)$ different values. However, Vanraja breed gizzards were showing significantly $(\mathrm{P}<0.05)$ higher values than all other chicken breeds.

Total Giblets: The content of sodium among all the chicken breeds giblets did not show any significant $(\mathrm{P}<0.05)$ difference with each other. Similarly potassium content in between the giblets of Cobb-400, Vanraja and Aseel as well as Cobb-400, Aseel and Kadaknath were showing no significant difference. However, Vanraja giblets was showing significantly $(\mathrm{P}<0.05)$ higher iron and zinc values than other breeds which were not significantly different with each other.

The average contents of minerals were higher in individual giblets as well as total giblets of all chicken breeds as reported in national food composition databases of Denmark (National Food Institute Denmark, 2009). The level of minerals in individual giblets and total giblets may vary not only according to the mineral content of feeds but also according to the way birds are housed, their breed, sex and health, slaughter procedures, and type of tissue (Połtowicz and Doktor, 2013).
On the basis of findings obtained in study it can be conclude that giblet accounts a good proportion on both live and cold weight basis. They are sound in Nutrition and the need is to process and preserve the giblets in good condition to extract full nutrition. Several value added products for humans as well as for animals can be generated using giblets.

\section{Acknowledgments}

Authors are highly thankful to the Hon'ble Vice-chancellor of the university to provide the requisite amount and facility to carry out the research work.

\section{References}

Chaosap, C., and K. Tuntivisoottikul. 2006. Carcass quality and some muscle properties of broiler, native, Sritong and Tanawsri chickens. Pages 52-60 in Proc. 43rd Annual Conference of Kasetsart University, Bangkok, Thailand.

Daros, F.G., M.L. Masson, and S.C. Amico. 2005. The influence of the addition of mechanically deboned poultry meat on the rheological properties of sausage. J. Food Eng., 68: 185-189.

Debata, D., B. Panigrahi, N. Panda, C.R. Pradha n, S. Kanungo, and P.K. Pati. 2012. Growth performance and carcass traits of Black Rock, Red Cornish and Vanaraja chicken reared in the coastal climatic condition of Odisha. Ind. J. Poul. Sci., 47(2): 214-217.

Demirbas, A. 1999. Proximate and heavy metal composition in chicken meat and tissues. Food Chem., 67: 27-31.

Gill, C.O. 1988. Microbiology of edible meat by-products. App. Sci., 5: 47-75.

ISO 1442. 1997. Meat and meat products. Determination of moisture content (Reference method), Switzerland: International Organisation for Standardisation.

ISO 1443. 1973. Meat and meat products. Determination of total fat content". Switzerland: International Organisation for 
Standardisation.

ISO 936. 1998. Meat and meat products. Determination of total ash". Switzerland: International Organisation for Standardisation.

ISO 937. 1978. Meat and meat products. Determination of nitrogen content (Reference method), Switzerland: International Organisation for Standardisation.

Jaturasitha, S., R. Khiaosaard, A. Pongpaew, A. Leawtharakul, S. Saitong, T. Apichatsarangkul, and V. Leaungwunta. 2004. Pages 116-126 in Proc. 42nd Annual Conference of Kasetsart University, Bangkok, Thailand.

Jokanović, M.R., V.M. Tomović, M.T. Jović, S.B. Škaljac, V. Šojib, P.M. Ikonić, and T.A. Tasić. 2014. Proximate and Mineral Composition of Chicken Giblets from Vojvodina (Northern Serbia). Int. J. Bio. Vet. Agri. Food Eng., 8 (9): 550-557.

Kgwatalala, P.M., A.M. Bolowe, K. Thutwa, and S.J. Nsoso. 2013. Carcass traits of the naked-neck, dwarf and normal strains of indigenous Tswana chickens under an intensive management system. Agri. Biol. J. North America, 4(4): 413-418.

National Food Institute Denmark. 2009. Technical University of Denmark. Available at: http://www.foodcomp.dk/v7/ fcdb_grpsearchres.asp?MainGrp=07.

Niranjan, M., R. P. Sharma, U. Rajkumar, R.N. Chatterjee, B.L.N. Reddy, and T.K. Battacharya. 2008. Egg quality traits in chicken varieties developed for backyard poultry farming in India. Lives. Res. Rural Dev., 20(12): 220-228.

Ockerman, H.W. and C.L. Hansen. 2000. Pages 105-107 in Animal By-Product Processing and Utilization. Lancaster, PA: Technomic. Olawumi, S.O., S.O. Fajemilehin, and S.S. Fagbuaro. 2012. Genotype $\times \quad$ Sex Interaction effects on carcass traits of three strains of commercial broiler chickens. $J$. World's Poult. Res., 2(1): 21-24.

Połtowicz, K. and J. Doktor. 2013. Macromineral concentration and technological properties of poultry meat depending on slaughter age of broiler chickens of uniform body weight, Animal Sci. Papers and Reports, 31: 249-259.

Romans, J.R., C.W. Carlson, W.J. Costello, M.L. Greaser, and K.W. Jones. 1994. The meat we eat. Danville, Interstate publishers Inc.

Shahin, K.A., and F.A. Elazeem. 2005. Effects of breed, sex and diet and their interactions on carcass composition and tissue weight distribution of broiler chickens. Arch. Tierztl., 48: 612-626.

Snedecor, G.W. and W.G. Cochran. 1994 Statistical Methods. 9th ed. Ames, Iowa, Iowa State University Press.

Somsen, D., A. Capelle, and J. Tramper. 2004. Production yield analysis in the poultry processing industry. J. Food Eng., 65: 479487.

Spooncer, W.F.1988. Organs and glands as human food. Pages $207-226$ in $5^{\text {th }}$ volume of Edible meat byproducts, Adv. Meat Res., Pearson, A. M. and Dutson T. R., eds. London and New York: Elsevier Applied Science.

Tazi, S.M.E., M.A. Mukhtar, K. Mohamed and M.H. Tabidi. 2014. Effect of using black pepper as natural feed additive on performance and carcass quality of broiler chicks. Inter. J. Pharm. Res. Anal., 4(2): 108-113.

\section{How to cite this article:}

Veer Pal Singh and Vikas Pathak. 2017. Quality Characterization of Giblets of Indigenous Indian Chicken Breeds. Int.J.Curr.Microbiol.App.Sci. 6(1): 784-797. doi: http://dx.doi.org/10.20546/ijcmas.2017.601.093 